Waterways Experiment

Station

\title{
Development of a Chronic Sublethal Bioassay for Evaluating Contaminated Sediment with the Marine Polychaete Worm Nereis (Neanthes) arenaceodentata
}

by Thomas M. Dillon, David W. Moore, Alfreda B. Gibson 


\section{Development of a Chronic Sublethal Bioassay for Evaluating Contaminated Sediment with the Marine Polychaete Worm Nereis (Neanthes) arenaceodentata}

by Thomas M. Dillon, David W. Moore, Alfreda B. Gibson

U.S. Army Corps of Engineers Waterways Experiment Station 3909 Halls Ferry Road

Vicksburg, MS 39180-6199

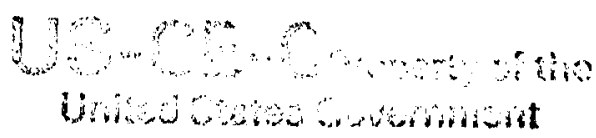

Final report

Approved for public release; distribution is unlimited

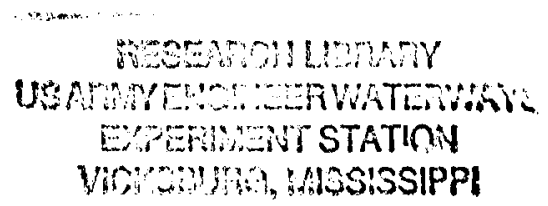

Prepared for U.S. Army Corps of Engineers Washington, DC 20314-1000 


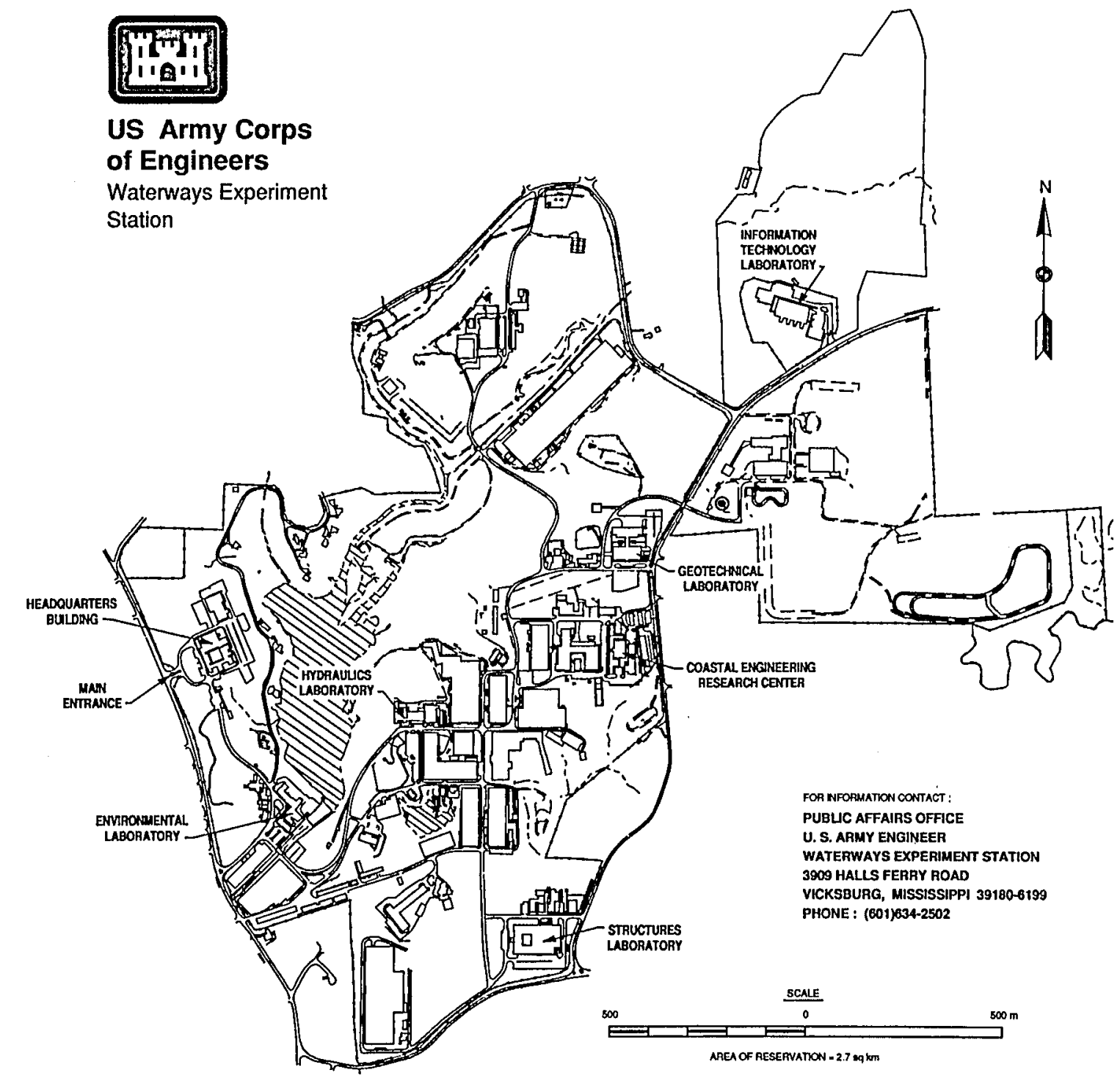

\section{Waterways Experiment Station Cataloging-in-Publication Data}

\section{Dillon, Tom M.}

Development of a chronic sublethal bioassay for evaluating contaminated sediment with the marine polychaete worm Nereis (Neanthes) arenaceodentata / by Tom M. Dillon, David W. Moore, Alfreda B. Gibson ; prepared for U.S. Army Corps of Engineers.

26 p. : ill. ; $28 \mathrm{~cm}$. - (Miscellaneous paper ; D-94-5) Includes bibliographic references.

1. Water - Pollution-Toxicology. 2. Dredging spoil - Testing.

3. Bioassay. 4. Nereis. I. Moore, David W. II. Gibson, A. B. III. United States. Army. Corps of Engineers. IV. U.S. Army Engineer Waterways Experiment Station. V. Long-Term Effects of Dredging Operations Program (U.S.) VI. Title. VII. Series: Miscellaneous paper (U.S. Army Engineer Waterways Experiment Station) ; D-94-5.

TA7 W34m no.D-94-5 


\section{Preface}

The work reported herein was conducted as part of the Long-Term Effects of Dredging Operations (LEDO) Research Program, Work Unit 32468. The LEDO is sponsored by the Headquarters, U.S. Army Corps of Engineers (HQUSACE), and is assigned to the U.S. Army Engineer Waterways Experiment Station (WES) under the purview of the Environmental Laboratory (EL). The LEDO is managed under the Environmental Effects of Dredging Programs, Dr. Robert M. Engler, Manager. Technical Monitor for LEDO is Mr. Joe Wilson, HQUSACE.

The principal investigators for this study were Drs. Tom Dillon and David Moore, Fate and Effects Branch (FEB), Environmental Processes and Effects Division (EPED), EL. Results of this study were first published as an article in Environmental Toxicology and Chemistry (Vol 12, 1993), reprints of which were provided for use in preparation of this report.

This investigation was performed under the general supervision of Dr. Bobby L. Folsom, Chief, FEB; Mr. Donald L. Robey, Chief, EPED; and Dr. John Harrison, Director, EL.

At the time of publication of this report, Director of WES was Dr. Robert W. Whalin. Commander was COL Bruce K. Howard, EN.

This report should be cited as follows:

Dillon, T. M., Moore, D. W., Gibson, A. B. (1994).

"Development of a Chronic Sublethal Bioassay for Evaluating Contaminated Sediment with the Marine Polychaete Worm Nereis (Neanthes) arenaceodentata," Miscellaneous Paper D-94-5, U.S. Army Engineer Waterways Experiment Station, Vicksburg, MS.

The contents of this report are not to be used for advertising, publication, or promotional purposes. Citation of trade names does not constitute an official endorsement or approval of the use of such commercial products. 


\title{
DEVELOPMENT OF A CHRONIC SUBLETHAL BIOASSAY FOR EVALUATING CONTAMINATED SEDIMENT WITH THE MARINE POLYCHAETE WORM NEREIS (NEANTHES) ARENACEODENTATA
}

\author{
Tom M. Dillon, * David W. Moore and Alfreda B. Gibson \\ U.S. Army Engineer Waterways Experiment Station, CEWES-ES-R, \\ 3909 Halls Ferry Road, Vicksburg, Mississippi 39180-6199
}

(Received 31 December 1991; Accepted 28 May 1992)

\begin{abstract}
Development of a chronic sublethal sediment bioassay with the polychaete Nereis ( Neanthes) arenaceodentata is described. The sublethal test end point was estimated individual somatic growth rate (milligrams dry weight per day). The test was initiated with two- to three-week-old postemergent juvenile worms and continued for $28 \mathrm{~d}$. The potential bias due to selected nontreatment factors on polychaete survival and growth was evaluated. For example, grain size had no significant effect, whereas the number of worms placed in each exposure vessel was critical. Direct transfer from $30 \%$ seawater to salinites $\leq 15 \%_{0}$ had a highly significant and adverse effect on survival and growth. Both survival and growth of juvenile worms may be adversely affected if test conditions involve exposures to $\geq 0.7 \mathrm{mg} / \mathrm{L}$ un-ionized ammonia or $\geq 5 \mathrm{mg} / \mathrm{L}$ hydrogen sulfide. Survival of juvenile worms to concentrations of the reference toxicant, cadmium chloride, approximating the $96-\mathrm{h} \mathrm{LC50}(5 \mathrm{mg} / \mathrm{L})$ was used as a quality control measure. Results are expressed in control chart format analogous to methods used in analytical chemistry.
\end{abstract}

Keywords-Chronic Sublethal Growth Sediment Neanthes

\section{INTRODUCTION}

First-generation bioassays in aquatic toxicology measured survival of sensitive species following short-term exposures to high concentrations of anthropogenic chemicals. Although these tests produced useful information for hazard assessments, they normally have not depicted environmentally realistic exposures, that is, chronic exposure to low concentrations of chemicals. Second-generation chronic bioassays have more closely approximated such field conditions. In these tests, overt lethality is less common but subtle sublethal responses (e.g., reduced growth and reproduction) are often observed. The frequency of this biological response has inextricably linked the two terms chronic and sublethal.

Most sediment bioassays are modifications of first-generation aquatic tests in which survival of very sensitive species is measured following acute exposure $[1,2]$. Chronic sublethal sediment bioassays, although fewer in number, are especially relevant because bioaccumulation of contaminants from a sediment matrix is a slow process compared to uptake from solution [3]. Thus, benthic infau-

*To whom correspondence may be addressed. nal organisms are typically exposed to a continuous (i.e., chronic) but low level of contamination. Because animals thus exposed will often respond in a subtle sublethal manner, chronic sublethal sediment bioassays need to be developed.

This communication reports on the development of such a test with the marine polychaete Nereis (Neanthes) arenaceodentata. Polychaetes are numerically dominant members of the benthic community [4], are important to energy flow and nutrient cycling [5-7], and significantly affect the physicochemical characteristics of sediments [8-10]. Thus, evaluating the potential impacts of contaminated sediments on polychaetes has substantial ecological importance.

\section{MATERIALS AND METHODS}

\section{Test species}

Nereis (Neanthes) arenaceodentata is a benthic infaunal polychaete widely distributed in shallow marine and estuarine benthic habitats of Europe, the Pacific, and all three coasts of North America [11-15]. This deposit feeder constructs one or more mucoid tubes in the upper 2 to $3 \mathrm{~cm}$ of sediment and ingests sediment particles up to $70 \mu \mathrm{m}$ with a preference for particles around $12 \mu \mathrm{m}$ [16]. Nereis 
(Neanthes) arenaceodentata is accepted in the regulatory community as an appropriate test species for evaluating sediment [17]. A substantial amount of toxicological data for a variety of environmental contaminants already exists for this species [18].

Taxonomists, however, are still debating the species' appropriate status. Pettibone [12], who suggested Nereis (Neanthes) arenaceodentata, listed five other names for this species: Spio caudatus, $\mathrm{Ne}$ reis (Neanthes) caudata, Nereis arenaceodentata, Neanthes cricognatha, and Neanthes caudata. Day [13] later submerged arenaceodentata in favor of acuminata, which was subsequently used by Taylor [15] and Weinberg et al. [19]. Neanthes arenaceodentata is the name most commonly used in the toxicological literature. Recent evidence suggests that Atiantic and Pacific populations are genetically dissimilar, reproductively isolated, and probably different species [19]. Until the taxonomic status of this species is resolved, we will report the original source of worms and use the name most familiar to toxicologists.

The life cycle of $N$. arenaceodentata is well documented $[11,20]$. As worms approach sexual maturity, males and females establish pairs and occupy a common tube. Females deposit eggs in the tube and the male presumably fertilizes the eggs at this time. The spent female exits the tube and dies within 1 to $2 \mathrm{~d}$ or is eaten by the male. The male remains in the tube to incubate and guard the developing eggs and embryos. He creates a current of water via rhythmic undulations to remove metabolic wastes and prevent hypoxic conditions. Larval development is direct via nonplanktonic metatrochophore larvae and occurs entirely within the parental tube. Emergent juveniles (EJs) exit the parental tube about three weeks after egg deposition. They establish tubes of their own and begin to feed. Juvenile worms grow and eggs become visible in the coelom of females at about six weeks postemergence. Egg deposition follows three to seven weeks later to complete the life cycle. Laboratory cultures maintained at 20 to $22^{\circ} \mathrm{C}$ typically require 12 to 16 weeks to complete the life cycle. The nonplanktonic benthic larvae and paternal care are unique among the Nereidae. These same features also facilitate laboratory culture and experimental investigations of the chronic sublethal effects.

\section{Laboratory cultures}

We have developed static-renewal culture methods by adapting the static procedures of Reish [21] and the flow-through methods of Pesch and Schauer [22]. Juvenile worms to initiate cultures were obtained from Dr. Don Reish, California State University (Long Beach). Worms are maintained at $20^{\circ} \mathrm{C}$ in $30 \%$ artificial seawater (Instant Ocean ${ }^{\circledR}$, Aquarium Systems, Mentor, $\mathrm{OH}$ ) made up with reverse osmosis water (ROW). The photoperiod is $12 \mathrm{~h}$ light. EJs are raised to adulthood in $38-\mathrm{L}$ allglass aquaria ( $50 \mathrm{EJs}$ per aquarium) containing $30 \mathrm{~L}$ of aerated seawater. Animals are fed a combination of finely ground TetraMin ${ }^{\oplus}$ (TetraWerke, Germany) flakes ( $2 \mathrm{mg}$ per worm) and alfalfa (1 mg per worm) twice weekly. This feeding regime is sufficient to maintain adequate water quality in a static-renewal system and has been found to produce survival and reproduction consistent with those reported for other laboratories for Neanthes (i.e., survival, $>80 \%$; fecundity, approximately 100-1,000 eggs per brood; EJ production, approximately 50-500 EJs per brood) [23-25]. Seawater is renewed ( $80 \%$ of volume) every three weeks. This renewal schedule is sufficient to maintain good water quality. After 10 weeks, worms are paired using the intrasexual fighting response and the presence or absence of eggs in the coelom [21]. Unpaired worms are not returned to culture. Pairs are placed in $600-\mathrm{ml}$ beakers with $500 \mathrm{ml}$ of $30 \% 0$ seawater. Each pair is initially fed once with a slurry containing $4 \mathrm{mg}$ Tetramin and $4 \mathrm{mg}$ alfalfa. Our experience indicates that paired worms eat very little before and after egg deposition. Gentle aeration is provided via Pasteur pipets, and the beakers are covered with watch glasses to reduce evaporation. Seawater is renewed weekly ( $80 \%$ of volume) by gently decanting overlying water and slowing renewal seawater to a gentle stream against the edge of the beaker to avoid disturbing worm pairs. Beakers are monitored daily for the presence of eggs and EJs. When discovered, EJs are removed for experiments or mixed with other broods and returned to the 38-L aquaria to complete the culture cycle. These culture conditions and feeding rations have been used in all experiments described below unless otherwise noted.

\section{Juvenile growth rates}

Growth of juvenile worms was determined weekly from the time of initial emergence from the parental tube to 12 weeks postemergence. EJs were taken from culture and randomly assigned to 4-L all-glass aquaria containing $3 \mathrm{~L}$ of seawater. There were three aquaria per sampling period and 12 worms per aquarium. Pesch et al. [24] reported that this stocking density ( $>21 \mathrm{~cm}^{2}$ per worm) had no adverse effect on survival, growth, and reproduction in $N$. arenaceodentata. Water-quality monitor- 
ing indicated that complete seawater renewal every three weeks was sufficient to avoid the buildup of ammonia. At weekly intervals, all worms were removed from three aquaria and counted. Individual worms were briefly rinsed in ROW, placed on small, tared aluminum pans, and dried at $60^{\circ} \mathrm{C}$ to a constant weight (approximately $24 \mathrm{~h}$ ). They were brought to room temperature under desiccation and weighed to the nearest $0.01 \mathrm{mg}$.

\section{Effect of sediment grain size on juvenile worms}

EJs were exposed for six weeks to a series of grain sizes created by diluting uncontaminated, natural, fine-grain sediment with muffled quartz sand. Surficial sediment was collected by hand from Range Point Pond, near Pensacola, Florida. This site is far removed from any known source of pollution and has been used historically as a control sediment by the U.S. Environmental Protection Agency (EPA) Environmental Research Laboratory at Gulf Breeze, Florida (Dr. Jim Clarke, personal communication). Sediment was gently sieved to remove the finest fraction $(<0.5 \mathrm{~mm})$ and proportionally diluted with $100 \%$ quartz sand (muffled at $500^{\circ} \mathrm{C}$ for $12 \mathrm{~h}$ ) to yield five grain-size treatments: $5,30,60,90$, and $100 \%$ sand. Nominal grain-size treatments were confirmed by particle-size analysis [26]. Sediment was layered in 4-L all-glass aquaria to a depth of 2 to $3 \mathrm{~cm}$. Three liters of seawater was added and gentle aeration provided. The next day, 12 EJs were randomly assigned to each aquarium, with three replicate aquaria per treatment. Seawater was completely renewed every three weeks. Worms within each replicate were removed after three and six weeks, counted, briefly rinsed in ROW, and placed on tared aluminum foil pans. They were dried at $60^{\circ} \mathrm{C}$ to a constant weight $(48 \mathrm{~h})$ and total dry-weight biomass determined to the nearest $0.01 \mathrm{mg}$. Estimated individual worm weights were calculated by dividing the total dry biomass by the number of surviving worms in each replicate.

\section{Effects of ammonium formate on dry-weight determinations}

Twenty juvenile worms (six weeks old) and 30 adult worms ( 10 weeks old) were removed from laboratory culture. Half the worms from each group were randomly selected and briefly rinsed in ROW to remove adhering salts before drying and weighing. The remaining worms were treated in the same manner, except that ammonium formate $(40 \mathrm{~g} / \mathrm{L})$ was substituted for the ROW rinse.

\section{Effects of intraspecific densities on juvenile worms}

EJs were randomly assigned to $600-\mathrm{ml}$ beakers containing $500 \mathrm{ml}$ of seawater at densities of 1,2 , 4,8 , and 12 worms per beaker. Two worms per beaker is equal to the optimal density reported by Pesch et al. [24] scaled downward to the surface area of the bottom of a $600-\mathrm{ml}$ beaker (approximately 60 $\mathrm{cm}^{2}$ ). There were five replicate beakers per treatment. Gentle aeration was provided and seawater renewed weekly. Animals were fed the normal laboratory food ration adjusted to the number of worms per beaker to prevent food from becoming a limiting factor at higher intraspecific densities. Survival and growth (as estimated individual dry weights) were determined after three and six weeks.

The presence of sediment in beakers adds a third dimension (height) to the worms' habitat and presumably the number of worms per beaker could be increased. To evaluate this possibility, the above beaker experiment was repeated with 2 to $3 \mathrm{~cm}$ of the Range Point Pond sediment $(90 \%$ sand treatment; see grain-size experiment above) layered on the bottom of each beaker. There were four replicates per treatment.

\section{Effects of salinity on juvenile worms}

Three-week-old juvenile worms were transferred directly from cultures (30\% seawater) to $600-\mathrm{ml}$ beakers containing $500 \mathrm{ml}$ of $30,25,20,15$, or $10 \%$ seawater. There were two worms per beaker and five beakers per treatment. Salinity was determined daily with a hand-held refractometer. Gentle aeration was provided and seawater renewed weekly. After three weeks, worms were counted and individual dry weights determined.

\section{Effects of ammonia on juvenile worms}

The effects of ammonia (as ammonium chloride) were determined using the same experimental design for salinity effects. Preliminary experiments indicated nominal total ammonia concentrations $(0$, $2.5,5.0,10,20$, and $40 \mathrm{mg} / \mathrm{L}$ ) were very stable under static-renewal conditions. During the toxicity test, water samples were taken before and after each weekly renewal to confirm nominal concentrations. Samples were adjusted to a pH of 2 with concentrated $\mathrm{HCl}$ and stored at $4^{\circ} \mathrm{C}$ for no longer than two weeks. Total ammonia was determined with an Orion $^{\oplus}$ (Orion Research, Boston, MA) ammoniaspecific electrode after adjusting sample $\mathrm{pH}$ to 12 with $5 \mathrm{~N} \mathrm{NaOH}$. Measured concentrations were converted to un-ionized ammonia, adjusting for 
temperature, $\mathrm{pH}$, and salinity using the equations of Hampson [27].

Resistance of juvenile worms to

hydrogen sulfide and hypoxia

Hydrogen sulfide occurs in aqueous solution only under hypoxic conditions. Because the two factors are inextricably linked, one should first evaluate the effects of hypoxia before evaluating hydrogen sulfide effects. Preliminary range-finding experiments indicated all juvenile worms survived $96 \mathrm{~h}$ at dissolved oxygen concentrations greater than about $2.0 \mathrm{mg} \mathrm{O}$ per liter. A definitive test was therefore conducted at nominal oxygen concentrations of $0.25,0.50,1.00$, and $1.50 \mathrm{mg} / \mathrm{L}$. The negative control was $6.50 \mathrm{mg} / \mathrm{L}$. Hypoxic conditions were created by metering high-purity nitrogen gas $(99.99 \%)$ into the normal laboratory air supply. Supply lines were fed through stoppered 1-L Erlenmeyer flasks containing $800 \mathrm{ml}$ of $30 \%$ seawater. The test was initiated the next day when each flask was briefly unstoppered, dissolved oxygen determined (YSI [Yellow Springs, OH] probe and meter), and five 3-week-old worms added. There were five replicate flasks per treatment. Temperature, salinity, $\mathrm{pH}$, dissolved oxygen, and survival were recorded on a daily basis; ammonia was determined at test termination $(96 \mathrm{~h})$. Worms were not fed.

Resistance to hydrogen sulfide was determined using the same experimental protocol as described above. All sulfide exposures were conducted at dissolved oxygen concentrations of $1.50 \mathrm{mg} \mathrm{O}_{2}$ per liter. There were two negative controls: normoxia (6.5 $\mathrm{mg} \mathrm{O}_{2}$ per liter) and hypoxia ( $1.5 \mathrm{mg} \mathrm{O}$ per liter). Each day fresh stock solutions of hydrogen sulfide were prepared by dissolving $60 \mathrm{~g}$ of sodium sulfide $\left(\mathrm{Na}_{2} \mathrm{~S} \cdot 9 \mathrm{H}_{2} \mathrm{O}\right)$ in $1 \mathrm{~L}$ of deoxygenated $(<0.5$ $\mathrm{mg} \mathrm{O}_{2}$ per liter) filtered $\mathrm{ROW}$. Nominal sulfide exposure concentrations $(2.5,5.0,10$, and $20 \mathrm{mg} / \mathrm{L}$ ) were created by adding small amounts of this primary dosing stock to each flask. Hydrogen sulfide concentrations were measured daily before and following additions from the primary dosing stock using a Hach ${ }^{\circledR}$ HS-7 test kit (Hach Company, Loveland, $\mathrm{CO}$ ). This kit makes use of the color reaction between lead acetate and hydrogen sulfide. Filter pads impregnated with lead acetate are exposed to effervescing water samples containing hydrogen sulfide. The ensuing color change in the filter pad is compared to a standardized chart accompanying the kit to yield a semiquantitative measurement of hydrogen sulfide.

\section{Reference toxicant tests}

The general viability of juvenile worms taken from cultures and used in these experiments was assessed by conducting reference toxicant tests with the heavy metal cadmium (as $\mathrm{CdCl}_{2}$ ). A range-finding toxicity test was initially conducted with juvenile worms exposed to nominal cadmium concentrations of $0,1,2,4,8$, and $16 \mathrm{mg} / \mathrm{L}$. Worms were randomly assigned to $600-\mathrm{ml}$ beakers (two per beaker) containing $500 \mathrm{ml}$ of solution. There were five replicates per treatment. Nominal exposure concentrations were analytically confirmed with an Orion specific-ion cadmium electrode. The resulting measured concentrations from this analysis were $0,1.2,2.0,3.8,6.5$, and $15.2 \mathrm{mg} / \mathrm{L}$ cadmium. $\mathrm{Re}-$ sults indicated $0 \%$ survival at $6.5 \mathrm{mg} / \mathrm{L}$ and $100 \%$ survival at $3.8 \mathrm{mg} / \mathrm{L}$ cadmium. The $96-\mathrm{h} \mathrm{LC} 50$ was calculated as the arithmetic mean of these two concentrations. Subsequent reference toxicant tests were conducted by measuring percentage of survival after $96 \mathrm{~h}$ exposure to a single concentration approximating the $\mathrm{LC50}(5.2 \mathrm{mg} / \mathrm{L}$ cadmium). Juvenile worms were placed in 600 -ml beakers (two per beaker) containing either 0 or $5 \mathrm{mg} / \mathrm{L}$ cadmium. There were five replicates for each treatment. Worms were not fed. Nominal exposure concentrations were analytically confirmed in each test. Reference toxicant tests were conducted about once a month.

\section{Statistical analysis}

Statistical analysis and data transformation were conducted using SYSTAT ${ }^{\oplus}$ statistical software [28]. Homogeneity of variance was examined for each biological end point using Box-Whisker plots. Dry weights were log transformed to normalize variance. Treatment effects were analyzed using analysis of variance (ANOVA) with subsequent mean separation via Tukey's HSD test [29]. All tests for significance were analyzed at a significance level of $\alpha=0.05$.

\section{Juvenile growth rate}

The growth of juvenile $N$. arenaceodentata measured as dry weight was essentially linear (Fig. 1). The pattern of growth can be partitioned into three periods of time. During the first week after emerging from the parental tube, there is no change in growth. Worms this age are only 1 to $2 \mathrm{~mm}$ long. After two to three weeks, they are approximately 4 to $6 \mathrm{~mm}$. This change in length is visually quite distinctive to the unaided eye. It is much easier and thus more accurate to locate and count two- to three-week-old worms than one- to two-week-old EJs. Postemergent growth is very linear up to eight weeks. At that time, dry weights depart slightly from linearity and become more variable. It is also 


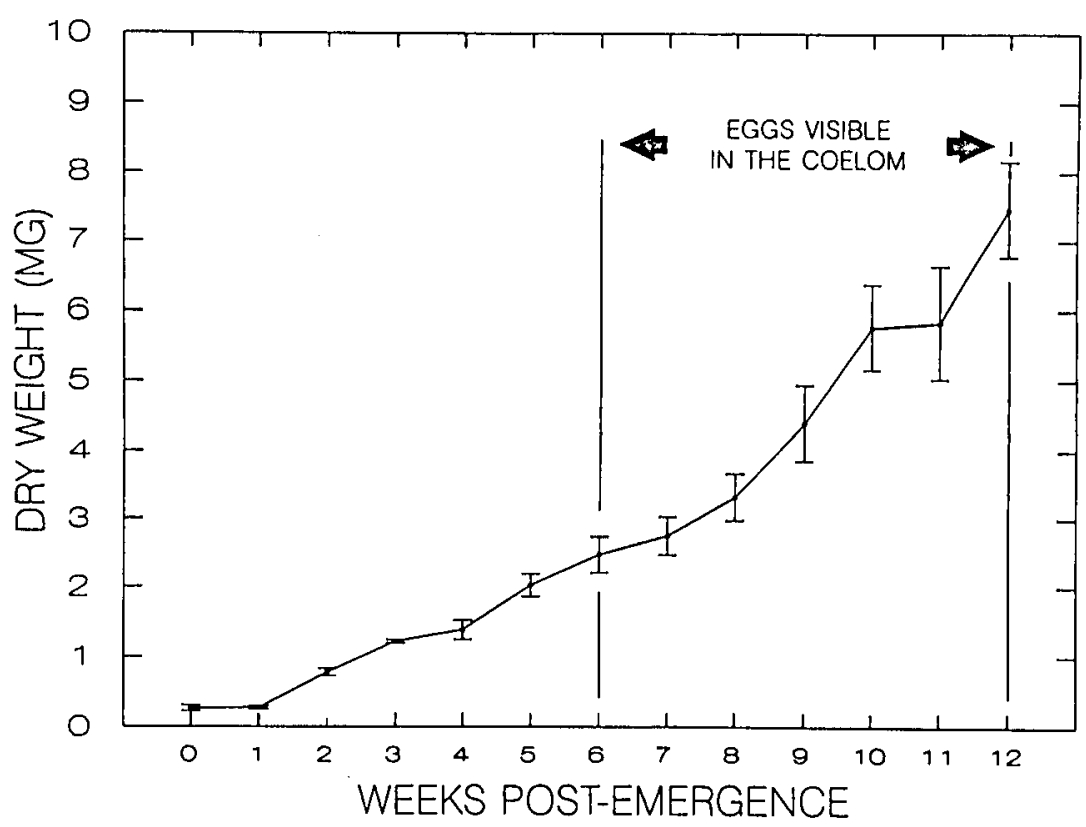

Fig. 1. Growth of Nereis (Neanthes) arenaceodentata between emergence from parental tube and sexual maturation. Data points $=$ mean $\pm S E$.

during this period when eggs in the coeloms of female worms become much larger and more numerous (Fig. 1).

\section{Measured vs. estimated individual dry weights}

In the above experiment, growth was determined by drying and weighing individual juvenile worms. This was very time consuming. A more expedient method and perhaps more precise approach would be to dry small groups of worms (replicates) and estimate individual worm weights by dividing total biomass by the number of individuals in that replicate. Both methods would theoretically yield the same mean dry weight. To compare these variances, data from the above juvenile growth experiment were used in the following simulation. We assumed that at each time period individual worms from each of the three aquaria had been pooled instead of weighed individually. These pooled worm samples were dried and the estimated individual dry weights were calculated from the total dry biomass. Results of this simulation are shown in Table 1. The variability (standard deviation, $\mathrm{SD}$, and percentage coefficient of variation, \%C.V.) associated with measured individual dry weights was always larger than that associated with estimated individual dry weights. The overall mean \%C.V. for the measured and estimated dry weights were 60 and $16 \%$, respectively.

\section{Ammonium formate}

Using ammonium formate instead of ROW to remove adhering salt before drying had no significant effect on determining dry weights in either juvenile or adult worms (Table 2). Rinsing juvenile worms in ammonium formate or ROW yielded the same mean dry weight $(0.36 \mathrm{mg})$, with the latter being slightly less variable $(\% \mathrm{C} . \mathrm{V} .=68 \%)$ than the former $(\%$ C.V. $=83 \%)$. Likewise, for adult worms, there was no significant difference between the ROW (mean $=4.44 \mathrm{mg} ; \%$ C.V. $=79 \%$ ) and the ammonium formate rinse (mean $=4.00 \mathrm{mg}$; $\%$ C.V. $=63 \%$ ).

\section{Effect of sediment grain size on juvenile worms}

Juvenile worms can tolerate a very wide range of grain sizes (Fig. 2). Survival was high $(89-100 \%)$ and unaffected after three and six weeks in grain sizes from 5 to $100 \%$ sand. Likewise, there was no significant effect of grain size on estimated individual worm growth after three or six weeks. However, there was a consistent trend of reduced worm weight with increasing grain size, which indicates a possibility for a chronic grain size effect with longer term exposures (greater than six weeks). Grain-size analysis closely mirrored nominal treatments (Table 3). 
Table 1. Variability associated with measured or estimated individual worm weights

\begin{tabular}{|c|c|c|c|c|c|c|c|}
\hline \multirow[b]{2}{*}{ Week } & \multirow{2}{*}{$\begin{array}{l}\text { Dry } \\
\text { wt. }^{a}\end{array}$} & \multicolumn{3}{|c|}{ Measured $^{b}$} & \multicolumn{3}{|c|}{ Estimated $^{\mathrm{c}}$} \\
\hline & & $n$ & SD & $\%$ C.V. & $n$ & SD & $\%$ C.V. \\
\hline 0 & 0.27 & 36 & 0.25 & 92 & 3 & 0.18 & 68 \\
\hline 1 & 0.27 & 36 & 0.14 & 50 & 3 & 0.04 & 13 \\
\hline 2 & 0.78 & 33 & 0.30 & 39 & 3 & 0.10 & 12 \\
\hline 3 & 1.21 & 28 & 0.70 & 57 & 3 & 0.26 & 21 \\
\hline 4 & 1.38 & 36 & 0.83 & 60 & 3 & 0.17 & 12 \\
\hline 5 & 2.02 & 36 & 0.98 & 49 & 3 & 0.18 & 9 \\
\hline 6 & 2.47 & 34 & 1.57 & 64 & 3 & 0.42 & 17 \\
\hline 7 & 2.75 & 35 & 1.68 & 61 & 3 & 0.42 & 14 \\
\hline 8 & 3.33 & 33 & 2.01 & 60 & 3 & 0.21 & 6 \\
\hline 9 & 4.40 & 29 & 3.12 & 71 & 3 & 0.87 & 20 \\
\hline 10 & 5.78 & 28 & 3.20 & 55 & 3 & 0.60 & 10 \\
\hline 11 & 5.84 & 31 & 4.48 & 77 & 3 & 0.13 & 4 \\
\hline 12 & 7.47 & 28 & 3.67 & 49 & 3 & 0.61 & 8 \\
\hline
\end{tabular}

Dry weights (milligrams) were determined 0 through 12 weeks postemergence. $n=$ number of worms or replicates in the measured or estimated dry weights, respectively.

${ }^{2}$ Mean dry weight of measured individual worms.

'Variation associated with measured individual dry weights.

'Variation associated with estimated dry weights; estimated = total biomass per number of individuals.

\section{Effects of intraspecific densities on juvenile worms}

In beakers without sediment, survival was high $(81 \%-100 \%)$ at intraspecific worm densities up to eight per beaker after three and six weeks (Fig. 3). Survival was significantly lower $(60 \%)$ after six weeks in the highest density tested (12 worms per beaker). Growth was unaffected after three weeks but was significantly diminished after six weeks at worm densities greater than or equal to four per beaker.

In the presence of sediment, survival was again high (81-100\%) and unaffected at worm densities up to 12 per beaker (Fig. 4). Growth was unaffected after three weeks exposure but significantly depressed after six weeks at densities greater than or equal to eight per beaker.

Table 2. Effects of ammonium formate (AM) and reverse-osmosis water (ROW) rinse on dry-weight (mg) determinations in juvenile and adult worms

\begin{tabular}{lcclll}
\hline & \multicolumn{2}{c}{ Juvenile worms } & & \multicolumn{2}{c}{ Adult worms } \\
\cline { 2 - 3 } \cline { 6 - 7 } & AM & ROW & & AM & ROW \\
\hline Mean & 0.36 & 0.36 & & 4.00 & 4.44 \\
(sD) & $(0.30)$ & $(0.25)$ & & $(2.50)$ & $(3.51)$ \\
$\%$ C.V. & $83 \%$ & $68 \%$ & & $63 \%$ & $79 \%$ \\
$n$ & 10 & 10 & & 15 & 15 \\
\hline
\end{tabular}

$n=$ number of replicates.

\section{Effects of salinity on juvenile growth}

There was a very sharp threshold response in juvenile worms acutely transferred from $30 \%$ seawater to lower salinities. Salinities $\geq 20 \%$ had no effect on either survival or growth (Fig. 5). No worms survived transfer to salinities $\leq 15 \%$.

\section{Effects of ammonia on juvenile growth}

Juvenile worms exhibited a very sharp threshold response to ammonia similar to that observed for salinity. Survival and growth were unaffected in juvenile worms exposed to 0,5 , and $10 \mathrm{mg} / \mathrm{L}$ nominal total ammonia concentrations $(0.001,0.20$, and $0.46 \mathrm{mg} / \mathrm{L}$ un-ionized ammonia, respectively) for three weeks (Fig. 6). Survival was always $100 \%$, and mean dry weights ranged from 2.66 to $2.81 \mathrm{mg}$. Both survival and dry weights $(80 \%$ and $1.84 \mathrm{mg}$, respectively) were slightly but not significantly diminished in worms exposed to $20 \mathrm{mg} / \mathrm{L}$ nominal total ammonia $(0.68 \mathrm{mg} / \mathrm{L}$ un-ionized ammonia). Survival was $0 \%$ in higher ammonia concentrations ( 40 and $60 \mathrm{mg} / \mathrm{L}$ nominal total or 1.25 and 2.02 $\mathrm{mg} / \mathrm{L}$ un-ionized, respectively). Measured ammonia concentrations were very stable over time (Table 4).

\section{Resistance of juvenile worms to hypoxia and hydrogen sulfide}

There was also a very sharp gradient in the resistance of juvenile worms to short-term (96-h) hyp- 

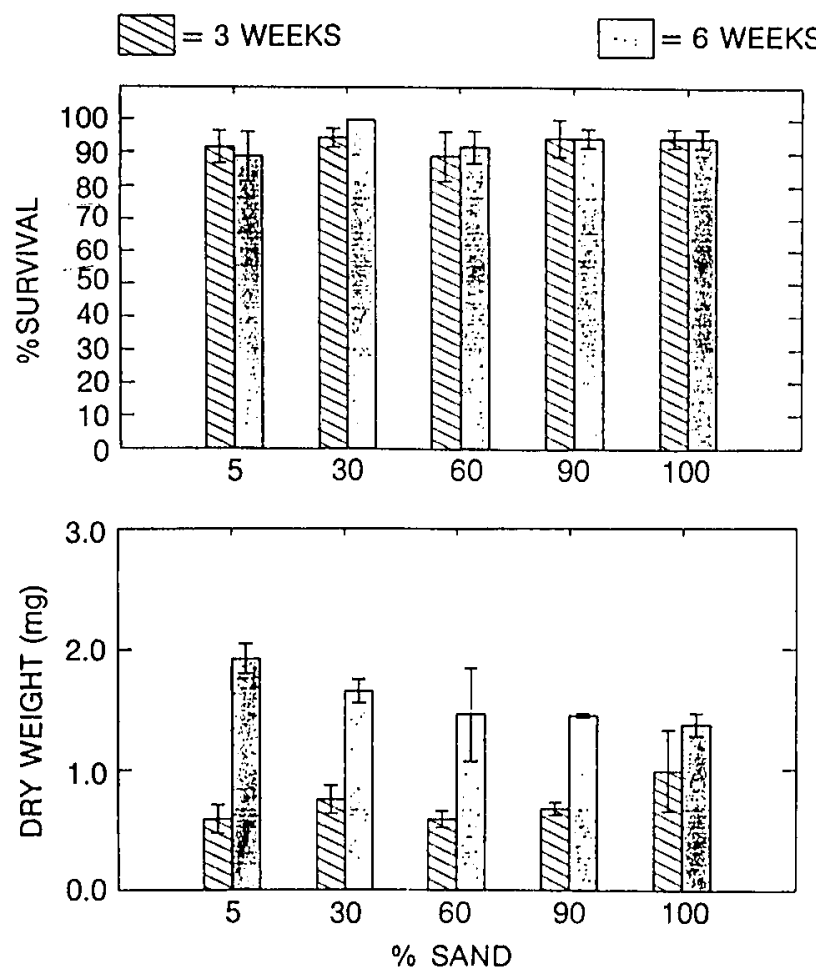

Fig. 2. Survival and growth (mg dry wt.) of juvenile Nereis (Neanthes) arenaceodentata after three and six weeks in sediments ranging from 5 to $100 \%$ sand. Vertical bars and lines $=$ mean \pm SE, respectively.

oxia. Percentage of survival was 100,68 , and $0 \%$ in $1.50,1.00$, and $0.50 \mathrm{mg} \mathrm{O}_{2}$ per liter, respectively (Table 5). Measured oxygen concentrations were very similar to nominal treatment values. Ammonia concentrations were virtually the same in all treatments at the end of the test (approximately 0.20 $\left.\mathrm{NH}_{3} \mathrm{mg} / \mathrm{L}\right)$, except in the $0.25 \mathrm{mg} \mathrm{O}$ per liter treatment, where low ammonia $\left(0.07 \mathrm{NH}_{3} \mathrm{mg} / \mathrm{L}\right)$ was the result of early $100 \%$ mortality.

Table 3. Particle-size analysis for sediment treatments in grain-size experiment

\begin{tabular}{lrrr}
\hline \multirow{2}{*}{$\begin{array}{l}\text { Treatment } \\
\text { (\% Sand) }\end{array}$} & Grain-size fraction \\
\cline { 2 - 4 } \% Sand & \% Silt & \% Clay \\
\hline 5 & $5(2.5)$ & $77(1.4)$ & $18(3.8)$ \\
30 & $29(0.5)$ & $42(2.5)$ & $28(2.5)$ \\
60 & $60(0.0)$ & $19(1.4)$ & $21(1.4)$ \\
90 & $90(0.0)$ & $8(1.4)$ & $2(1.4)$ \\
\hline
\end{tabular}

Mean (SD), $n=3$.
Survival of juvenile worms appeared to be unaffected at sulfide concentrations $\leq 5.0 \mathrm{mg} / \mathrm{L}$ and adversely affected at concentrations $\geq 10.0 \mathrm{mg} / \mathrm{L}$ (Table 6). Mean survival at nominal concentrations of $2.5,5.0,10.0$, and $20.0 \mathrm{mg} / \mathrm{L}$ were $100,100,44$, and $0 \%$, respectively (Table 6). Initial measured sulfide concentrations generally mirrored nominal sulfide values. However, after $24 \mathrm{~h}$ (just before renewal), measured sulfide concentrations were generally about half of the initial values. Measured oxygen concentrations approximated the threshold level, where juvenile worm survival is affected by short-term hypoxic exposures $(0.50-1.50 \mathrm{mg} \mathrm{O}$ per liter). This proximity to the hypoxia threshold might have affected and obscured the response of worms to the sulfide treatments.

\section{Reference toxicant tests}

To date, a total of 13 reference toxicant tests with cadmium have been conducted. These data are summarized in Table 7. The grand mean percentage of survival of juvenile worms exposed to $5.0 \mathrm{mg} / \mathrm{L}$ 

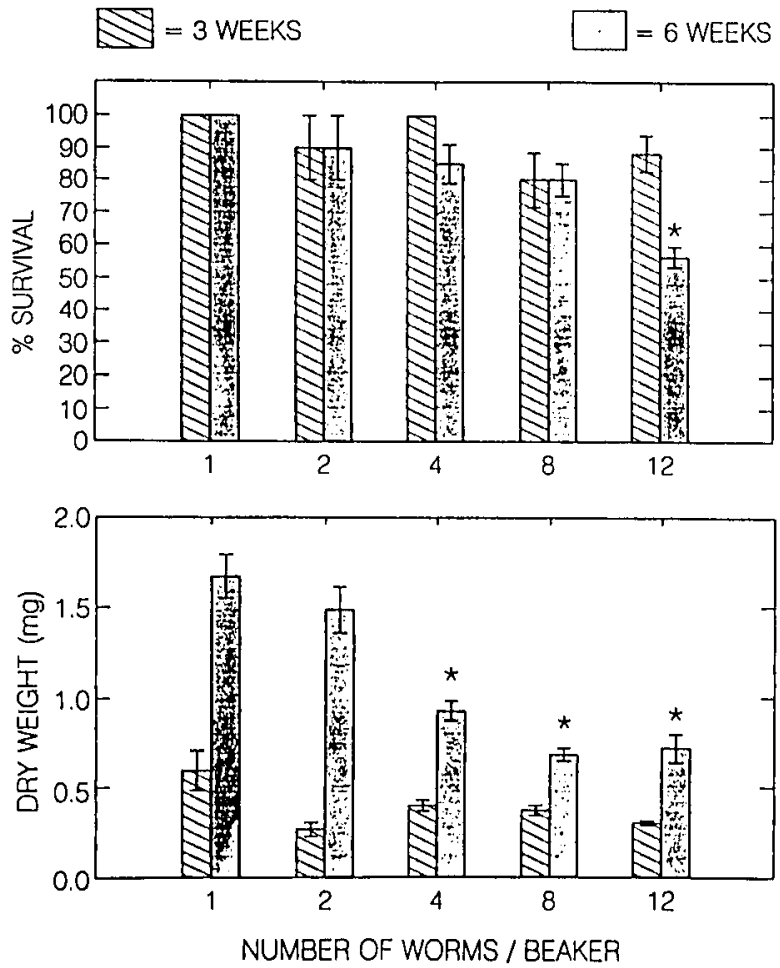

Fig. 3. Survival and growth (mg dry wt.) of juvenile Nereis (Neanthes) arenaceodentata after three and six weeks at densities ranging from 1 to 12 worms per 600 -ml beaker. Sediment absent. Vertical bars and lines $=$ mean \pm SE, respectively. Star = significantly less than other treatments.

nominal concentration of cadmium was $75 \% \pm 30$ (SD). The measured grand mean cadmium concentration in the exposure water $(4.99 \mathrm{mg} / \mathrm{L} \pm 1.14 \mathrm{sD})$ was very close to the nominal value. Data in Table 7 were used to construct a control chart (Fig. 7) similar to those used by analytical chemists. With one exception (test 9), survival was always within one standard deviation $(1 \sigma)$ of the grand mean. That one exception occurred when measured cadmium concentrations were relatively high. With one exception (test 13), measured cadmium concentrations were always within one standard deviation of the grand mean. That one exception occurred when the highest survival was observed.

Table 4. Un-ionized ammonia in exposure vessels at the beginning $\left(\mathrm{B}-\mathrm{NH}_{3}\right)$ and end $\left(\mathrm{E}-\mathrm{NH}_{3}\right)$ of each week during the 21-d ammonia toxicity test

\begin{tabular}{|c|c|c|c|c|c|c|}
\hline \multirow{2}{*}{$\begin{array}{l}\text { Nominal } \\
\mathrm{NH}_{3} \text { conen. }\end{array}$} & \multicolumn{2}{|c|}{ Week 1} & \multicolumn{2}{|c|}{ Week 2} & \multicolumn{2}{|c|}{ Week 3} \\
\hline & B- $\mathrm{NH}_{3}$ & $\mathrm{E}-\mathrm{NH}_{3}$ & B-NH ${ }_{3}$ & $\mathrm{E}-\mathrm{NH}_{3}$ & B- $-\mathrm{NH}_{3}$ & $\mathrm{E}-\mathrm{NH}_{3}$ \\
\hline 0 & $0.002(0.002)$ & $0.020(0.001)$ & $0.001(0.001)$ & $0.029(0.003)$ & $0.001(0.001)$ & $0.028(0.003)$ \\
\hline 5 & $0.180(0.004)$ & $0.219(0.004)$ & $0.202(0.004)$ & $0.211(0.001)$ & $0.200(0.006)$ & $0.171(0.004)$ \\
\hline 10 & $0.404(0.012)$ & $0.528(0.041)$ & $0.534(0.010)$ & $0.429(0.042)$ & $0.448(0.087)$ & $0.423(0.030)$ \\
\hline 20 & $0.550(0.018)$ & $0.877(0.046)$ & $0.786(0.059)$ & $0.654(0.020)$ & $0.653(0.010)$ & $0.561(0.010)$ \\
\hline 40 & $0.937(0.023)$ & $1.550(0.006)$ & $1.319(0.045)$ & $1.180(0.049)$ & a & \\
\hline 60 & $1.590(0.002)$ & $2.404(0.084)$ & $2.252(0.053)$ & $1.858(0.049)$ & a & \\
\hline
\end{tabular}

Nominal concentrations are total ammonia (milligrams per liter). Mean (sD), $n=5$.

"Treatment terminated due to $100 \%$ mortality. 

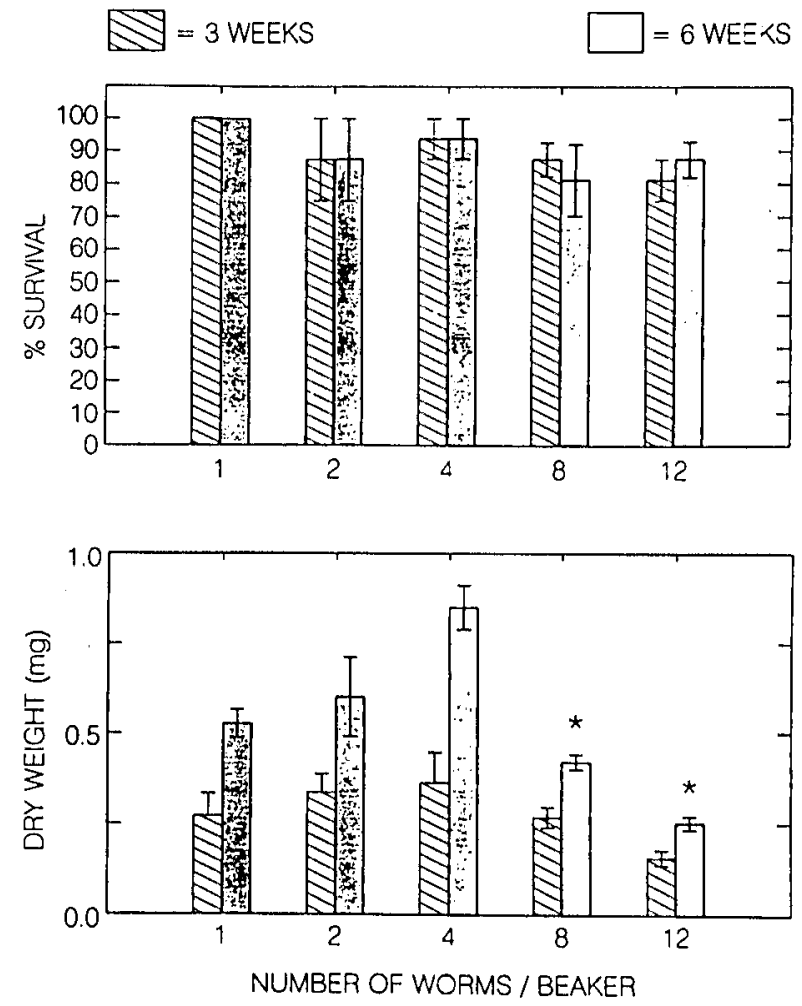

Fig. 4. Survival and growth (mg dry wt.) of juvenile Nereis (Neanthes) arenaceodentata after three and six weeks in sediment at intraspecific densities ranging from 1 to 12 worms per $600 \mathrm{ml}$ beaker. Vertical bars and lines = mean $\pm S E$, respectively.

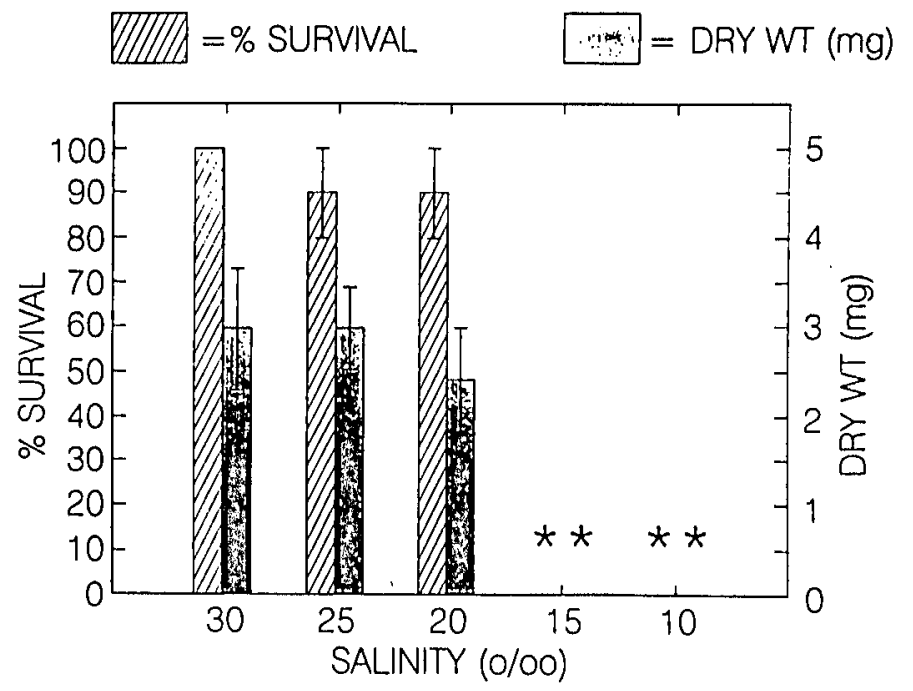

Fig. 5. Survival and growth of juvenile Nereis (Neanthes) arenaceodentata three weeks after acute transfer from $30 \%$ to salinities ranging from 10 to $30 \%$. Vertical bars and lines $=$ mean $\pm S E$, respectively. Stars $=$ significantly less than other treatments. 


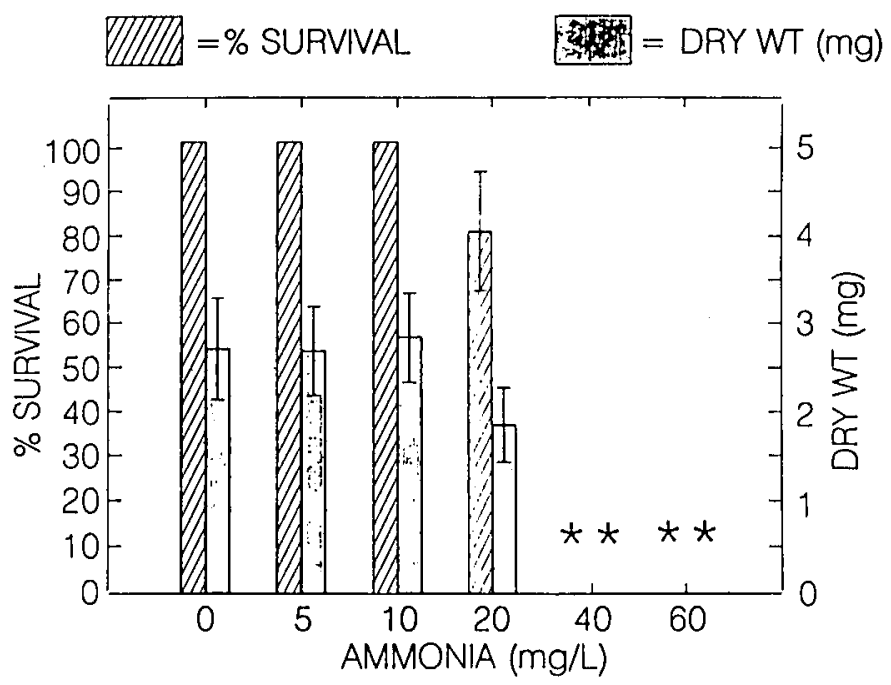

Fig. 6. Survival and growth of juvenile Nereis (Neanthes) arenaceodentata three weeks after acute transfer to total ammonia concentrations ranging from 0 to $60 \mathrm{mg} / \mathrm{L}$. Vertical bars and lines $=$ mean $\pm \mathrm{SE}$, respectively. Stars $=$ significantly less than other treatments.

\section{DISCUSSION}

\section{Juvenile worm growth}

The growth rate of juvenile $N$. arenaceodentata is very linear, especially between one and eight weeks postemergence. During the first week, some EJs still retain substantial egg yolk. This remnant yolk can be visualized through a dissecting scope as a yellow-tan protuberance on the dorsal surface near the anterior end. EJs with remnant yolk have no food in their gut and presumably have not yet begun to feed. This may explain why no net growth was observed during the first week postemergence.
By the end of the second week, all juvenile worms have food in their guts. For this reason, measures of growth should probably not be initiated any sooner than two weeks postemergence.

Around eight weeks postemergence, the dry weight of worms becomes more variable. Sexual dimorphism may explain this increased variability. The earliest observation of eggs in the coelom occurs around six weeks postemergence, which is very similar to the pattern reported by Reish [11], who noted eggs in the coelom around five weeks postemergence. With time, an increasing number of worms have eggs in their coeloms and egg size in-

Table 5. Survival of juvenile worms and water-quality parameters during 96 -h exposure to low oxygen $\left(\mathrm{O}_{2}\right)$ conditions

\begin{tabular}{lcccc}
\hline $\begin{array}{l}\text { Nominal } \mathrm{O}_{2} \\
\text { concn. }(\mathrm{mg} / \mathrm{L})\end{array}$ & $\begin{array}{c}\text { Survival } \\
(\%)\end{array}$ & $\begin{array}{c}\mathrm{DO} \\
(\mathrm{mg} / \mathrm{L})\end{array}$ & $\begin{array}{c}\mathrm{NH}_{3} \\
(\mathrm{mg} / \mathrm{L})\end{array}$ & $\mathrm{pH}$ \\
\hline 6.50 (Controls) & $100(0)$ & $6.64(0.27)$ & $0.22(0.04)$ & $n .86(0.19)$ \\
& $n=5$ & $n=25$ & $n=5$ & $n=20$ \\
1.50 & $100(0)$ & $1.34(0.26)$ & $0.21(0.08)$ & $n .18(0.11)$ \\
& $n=5$ & $n=25$ & $n=5$ & $n=20$ \\
1.00 & $68(16)$ & $1.03(0.19)$ & $0.21(0.08)$ & $8.42(0.11)$ \\
& $n=5$ & $n=25$ & $n=5$ & $n=20$ \\
0.50 & $0(0)$ & $0.50(0.10)$ & $0.20(0.07)$ & $n=5$ \\
0.56 & $n=5$ & $n=15$ & $0.07)$ \\
0.25 & $0(0)$ & $n=107(0.03)$ & $n=10$ \\
& $n=5$ & $n=11$ & $n=5$ & $8.69(0.04)$ \\
& & & & $n=6$ \\
\hline
\end{tabular}

Mean (SD), $n=$ number of replicates. 
Table 6. Percentage of survival of juvenile worms and water-quality parameters during 96-h exposure to hydrogen sulfide and low oxygen $\left(\mathrm{O}_{2}\right)$ conditions

\begin{tabular}{lccccc}
\hline $\begin{array}{l}\text { Nominal } \mathrm{H}_{2} \mathrm{~S} \\
\text { concn. }(\mathrm{mg} / \mathrm{L})\end{array}$ & $\begin{array}{c}\text { Survival } \\
(\%)\end{array}$ & $\begin{array}{c}\mathrm{H}_{2} \mathrm{~S} \\
(\mathrm{mg} / \mathrm{L})\end{array}$ & $\begin{array}{c}\mathrm{DO} \\
(\mathrm{mg} / \mathrm{L})\end{array}$ & $\begin{array}{c}\mathrm{NH}_{3} \\
(\mathrm{mg} / \mathrm{L})\end{array}$ & $\mathrm{pH}$ \\
\hline 0.0 (High $\mathrm{O}_{2}$ control) & $88(18)$ & $0.0(0)$ & $6.59(0.36)$ & $0.27(0.03)$ & $8.18(0.03)$ \\
& $n=5$ & $n=5$ & $n=20$ & $n=5$ & $n=20$ \\
0.0 (Low $\mathrm{O}_{2}$ control) & $52(23)$ & $0.0(0)$ & $1.03(0.16)$ & $0.24(0.04)$ & $8.52(0.08)$ \\
& $n=5$ & $n=5$ & $n=20$ & $n=5$ & $n=20$ \\
2.5 & $100(0)$ & $1.4(1.3)$ & $1.33(0.12)$ & $0.32(0.03)$ & $8.77(0.05)$ \\
& $n=5$ & $n=5$ & $n=20$ & $n=5$ & $n=20$ \\
5.0 & $100(0)$ & $3.4(1.4)$ & $1.74(0.19)$ & $0.24(0.07)$ & $8.84(0.06)$ \\
& $n=5$ & $n=5$ & $n=15$ & $n=5$ & $n=20$ \\
10.0 & $44(30)$ & $5.5(2.9)$ & $1.20(0.31)$ & $0.16(0.09)$ & $8.87(0.34)$ \\
& $n=5$ & $n=4$ & $n=20$ & $n=5$ & $n=20$ \\
20.0 & $0(0)$ & $15.0(4.1)$ & $0.96(0.12)$ & $0.45(0.08)$ & $9.42(0.20)$ \\
& $n=5$ & $n=3$ & $n=15$ & $n=5$ & $n=15$ \\
\hline
\end{tabular}

Mean (sD), $n=$ number of replicates.

creases to between 450 and $500 \mu \mathrm{m}$. Just before egg deposition, the female's coelom is literally packed with eggs to the virtual exclusion of any other internal tissue. Thus, advancing oogenesis in female worms probably explains why dry-weight growth becomes more variable beyond six to eight weeks postemergence. To minimize this source of variability and to keep somatic growth separate from reproductive growth, observations should probably not be made later than six weeks postemergence.

Table 7. Summary of reference toxicant tests with cadmium

\begin{tabular}{cccc}
\hline $\begin{array}{l}\text { Test } \\
\text { no. }\end{array}$ & $\begin{array}{c}\text { No. of } \\
\text { replicates }\end{array}$ & $\begin{array}{c}\text { Survival } \\
(\%)\end{array}$ & $\begin{array}{c}\text { Measured Cd } \\
\text { concn. (mg/L) }\end{array}$ \\
\hline 1 & 3 & $67(4.7)$ & $5.00(0.00)$ \\
2 & 6 & $87(11)$ & $4.78(0.97)$ \\
3 & 3 & $47(4.7)$ & $6.00(0.00)$ \\
4 & 3 & $80(28)$ & $5.90(0.08)$ \\
5 & 5 & $70(24)$ & $4.80(0.61)$ \\
6 & 5 & $90(20)$ & $4.80(0.61)$ \\
7 & 5 & $60(37)$ & $5.66(0.14)$ \\
8 & 10 & $60(37)$ & $5.68(0.57)$ \\
9 & 5 & $30(24)$ & $6.00(0.00)$ \\
10 & 5 & $80(24)$ & $5.92(0.10)$ \\
11 & 10 & $85(23)$ & $4.23(1.53)$ \\
12 & 5 & $90(20)$ & $5.48(0.10)$ \\
13 & 10 & $100(0.0)$ & $3.21(0.18)$ \\
& & $75(30)^{a}$ & $4.99(1.14)^{a}$ \\
\hline
\end{tabular}

Survival was determined after 96-h exposure to the approximate $96-\mathrm{h}$ LC50 (5.0 mg/L). All nominal concentrations were analytically confirmed. Control survival was $100 \%$ in all tests (mean [SD]).

Overall mean (SD), $n=75$.
Reish [11] measured segment number in juvenile $N$. arenaceodentata and reported linear growth between emergence (18-21 segments) and five weeks of age (approximately 50-60 segments). Segment number increased only slightly thereafter. A similar pattern of growth in segment numbers has been reported for the congener species, $N$. diversicolor [30]. These published observations, when combined with the pattern of linear growth reported here for $N$. arenaceodentata, suggest a common growth paradigm for nereid polychaetes. That is, both mass and segment number increase early in development when somatic growth dominates. Later, as worms become more sexually mature, the primary increase in growth is reflected in mass changes. As sexual maturation nears, energy reserves and yolk precursors in $N$. arenaceodentata are transferred from internal musculature to oocytes via freely circulating cells called eleocytes [31]. This is consistent with the more general observations in nereid polychaetes that vitellogenesis is primarily extraovarian [32] and that somatic growth and gametic growth are energy antagonists [33].

Based on the above, we speculate that germ cells in $N$. arenaceodentata pass through initial oogenesis and enter the previtellogenic (nonyolk) phase around six weeks postemergence. Between six and eight weeks, vitellogenesis becomes active, and the gametic mass becomes a quantitatively important component of total body mass. To eliminate the confounding influence of gametic growth on the measurement and interpretation of somatic growth in juvenile $N$. arenaceodentata, dry weight measurements should be made before the onset of vi- 


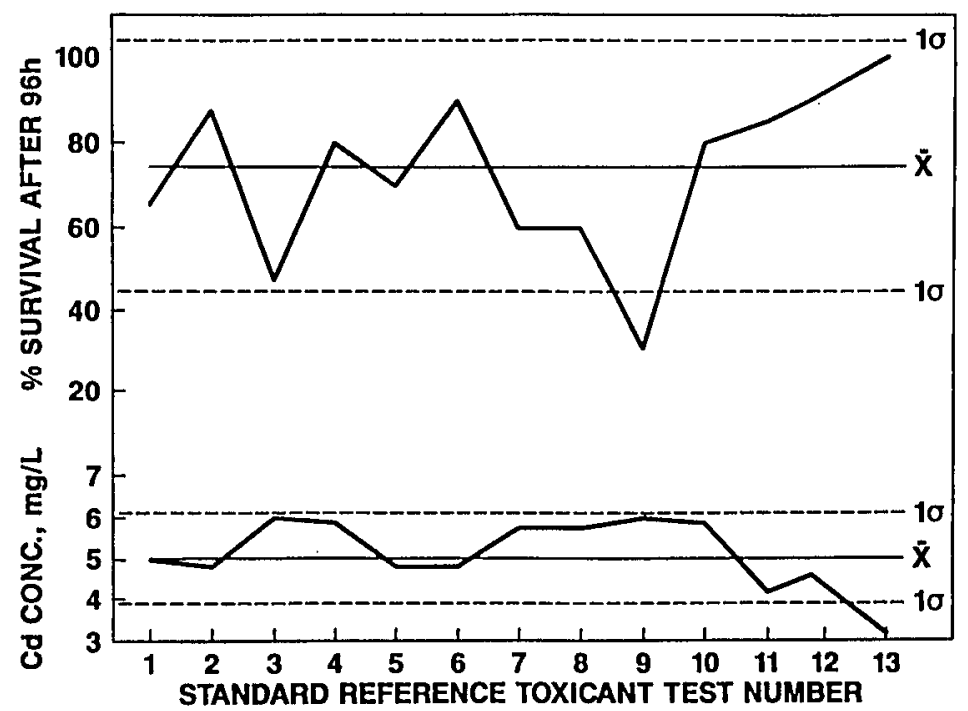

Fig. 7. Control chart summarizing 13 cadmium reference toxicant tests with juvenile Nereis (Neanthes) arenaceodentata. Upper line is the survival of worms exposed to the approximate $96-\mathrm{h} \mathrm{LC50}(5 \mathrm{mg} \mathrm{Cd} / \mathrm{L})$. Lower line is the measured cadmium concentrations in the exposure water. $\bar{X}=$ grand mean, $1 \sigma=$ one SD of the grand mean.

tellogenesis (approximately seven to eight weeks postemergence).

It is recommended that juvenile worm growth be expressed as a rate function according to the formula

$$
G=\frac{D W_{1}-D W_{\mathrm{i}}}{T}
$$

where

$G=$ estimated individual growth rate (milligrams dry weight $\cdot$ day $^{-1}$ )

$D W_{\mathrm{t}}=$ estimated individual dry weight at termination (milligrams)

$D W_{\mathrm{i}}=$ mean estimated individual dry weight at initiation (milligrams)

$T=$ exposure time (days).

Expressing growth as a rate function (milligrams per day) rather than as an absolute dry weight (milligrams) has several advantages. First, all bioassays will not be initiated with the same size worms. Expressing growth as a rate will normalize test results for these differences. Second, expressing growth as a rate will permit the experimental flexibility to vary slightly from any recommended exposure period (e.g., 28 d). Third, because differences due to initial worm size and test duration are normalized by the rate function, intra- as well as interlaboratory comparisons are possible. Fourth, expressing growth as a rate function will, with time and experience, allow us to establish quality-control criteria for test acceptance or rejection. For example, we may eventually be able to evaluate the validity of a sediment bioassay on the basis of the observed growth rate in control or reference treatments. Finally, much of the published literature on polychaete growth is expressed as a rate function. Expressing bioassay test results as a rate will facilitate comparisons to these literature reports.

\section{Nontreatment factors}

To have regulatory utility, a sediment bioassay must be able to assess the effects of sediment-associated anthropogenic chemicals without the confounding influence of nontreatment factors such as sediment grain size, intraspecific density, ammonia toxicity, and so forth. Although it is important to estimate the influence of these nontreatment biases in acute tests, it is critical to do so for chronic sublethal sediment bioassays. This is because the biological response in chronic tests is likely to be more subtle (i.e., sublethal) and thus more susceptible to bias from nontreatment factors. For these reasons, important nontreatment effects on survival and growth in $N$. arenaceodentata were evaluated.

Benthic species often show a preference for specific grain sizes. For example, Rhepoxynius abronius, a marine amphipod used widely in sediment bioassays, occurs in well-sorted sand and does not 
tolerate fine-grain silty material [34]. Because finegrain material often carries a higher contaminant load, mortalities from physical impacts can confound bioassay test results and render interpretation equivocal.

The field distribution of nereid polychaetes is associated with differences in grain size [35]. This distribution reflects not only sediment preferences and tolerances, but also the physical energy of different systems as well as available food sources. Results reported here indicate that survival of $N$. arenaceodentata is unaffected by a wide range of grain sizes (5-100\% sand). Similarly, the mean dry weights of $N$. arenaceodentata showed no statistically significant differences for the tested range of sediment grain sizes. However, there was a consistent trend of reduced worm weight with increasing grain size, which indicates a possibility for a chronic grain-size effect with longer term exposures (greater than six weeks). Field observations show that $N$. arenaceodentata inhabits sediments ranging from 2.6 to $87.6 \%$ silt and clay [14]. Thus, for this species, differences in grain size do not appear to be an important nontreatment factor in short-term (less than six weeks) sediment bioassays.

Intraspecific densities can adversely affect survival, growth, and reproduction in $N$. arenaceodentata [24]. These adverse effects are believed to be the result of more frequent aggressive encounters among worms. This explanation is firmly based in the numerous reports of intraspecific aggression in nereid polychaetes and especially in $N$. arenaceodentata [35-37]. We have confirmed that the growth of juvenile $N$. arenaceodentata in the absence of sediment is unaffected when held for three weeks at the same no-effect density reported by Pesch et al. [24]. The presence of sediment permits slightly higher worm densities. This enhanced survival and growth are probably due to two factors. One, sediment essentially adds a third dimension, depth, to the exposure vessel. As a result, the frequency of aggressive encounters is probably diminished. Two, $N$. arenaceodentata is a natural infaunal burrower with a strong thigmotactic requirement. The presence of sediments is likely to reduce the general level of biological stress by meeting this requirement.

Ammonia is highly toxic to many fish and aquatic invertebrates. Acutely lethal concentrations of un-ionized ammonia (48-96-h LC50s) range from about 0.5 to $2.0 \mathrm{mg} / \mathrm{L}$ and acute:chronic ratios from about 5 to 20 [38]. In both freshwater and marine sediments, ammonia is derived primarily via the hydrolysis of macromolecules and subsequent deamination of amino acids [39]. Interstitial total ammonia concentrations near the sediment surface are about $1 \mathrm{mg} / \mathrm{L}$ and increase with depth to around 20 to $50 \mathrm{mg} / \mathrm{L}[9,40,41]$. Jones and Lee [42] suggested that ammonia may be an important reason toxicity is observed in many marine sediment bioassays. More recently, Ankley et al. [41] demonstrated that ammonia was the primary cause of toxicity in freshwater sediments containing substantial amounts of anthropogenic chemicals. As Ankley et al. [41] point out, if ammonia is the causative agent in most sediment toxicity bioassays, then past interpretations regarding potential environmental impacts of many sediments might have been erroneous.

Results reported here for $N$. arenaceodentata suggest that juvenile worms are adversely affected by ammonia when exposed for three weeks to concentrations $\geq 20 \mathrm{mg} / \mathrm{L}$ total ammonia $(>0.68 \mathrm{mg} / \mathrm{L}$ un-ionized ammonia). As noted above, sediments may have interstitial ammonia concentrations that meet or exceed these levels. Another important consideration is the actual in situ exposures for $N$. arenaceodentata. Aller and Yingst [8] demonstrated that the burrow wall of a deposit-feeding polychaete, Amphitrite ornata, is the size of intense decomposition. They reported higher total ammonia concentrations at the burrow wall $(10-20 \mathrm{mg} / \mathrm{L})$ than in the surrounding interstitial waters ( $1-8$ $\mathrm{mg} / \mathrm{L}$ ). Irrigation of the worm tube may act to partially of fset these elevated total ammonia concentrations. Additional measures of ammonia in the worm's microenvironment are needed before we can assess the importance of ammonia as a nontreatment factor.

Benthic animals have developed adaptive physiologic, biochemical, and behavioral strategies to survive low-oxygen environments [43]. Although $N$. arenaceodentata can survive very hypoxic conditions, it does appear to have a very sharp threshold response at near-anoxic levels $(0.5-1.5 \mathrm{mg} / \mathrm{L})$. Davis and Reish [31] exposed female worms to low dissolved oxygen concentrations for $56 \mathrm{~d}$. Survival and fecundity were unaffected at concentrations as low as $3 \mathrm{mg} / \mathrm{L}$. At $2 \mathrm{mg} / \mathrm{L}$, fecundity was reduced by $50 \%$; at $1 \mathrm{mg} / \mathrm{L}$, both survival and fecundity were severely impacted. Although surficial sediments can be hypoxic and deeper layers completely anoxic, $N$. arenaceodentata, like many other tube dwellers, avoids hypoxic conditions by drawing overlying water through its tube via rhythmic undulations. Therefore, as long as overlying water is aerated, hypoxic conditions will probably not be an important nontreatment factor in ehronic sublethal sediment bioassays with $N$, arenaceodentata. 
Hydrogen sulfide $\left(\mathrm{H}_{2} \mathrm{~S}\right)$ is a metabolic poison that is lethal to many fish and invertebrate species at concentrations $<1 \mathrm{mg} / \mathrm{L}[44,45] . \mathrm{H}_{2} \mathrm{~S}$ is almost always associated with hypoxic conditions because sulfide is rapidly oxidized to $\mathrm{SO}_{4}$ or elemental sulfur in the presence of oxygen [46]. Thus, $\mathrm{H}_{2} \mathrm{~S}$ and hypoxia are two environmental conditions that are inextricably linked. Their close association also renders laboratory assessments of sulfide toxicity problematic. For $N$. arenaceodentata, the situation is exacerbated by the fact that it has a very sharp threshold response under very hypoxic conditions. In these experiments, all worms survived hydrogen sulfide concentrations $\leq 3.4 \mathrm{mg} / \mathrm{L}$. At slightly higher concentrations $(5.5 \mathrm{mg} / \mathrm{L})$ survival was reduced to $44 \%$, whereas at higher concentrations ( 15 $\mathrm{mg} / \mathrm{L}$ ) survival was $0 \%$. The dissolved oxygen concentration in these latter two treatments, 1.2 and 1.7 $\mathrm{mg} / \mathrm{L}$, respectively, approximated hypoxia threshold levels. Thus, the observed mortality may be due to either $\mathrm{H}_{2} \mathrm{~S}$ or hypoxia, or both.

Assigning causality to either $\mathrm{H}_{2} \mathrm{~S}$ or hypoxia in this data set becomes less critical when one considers in situ sediment exposures to $\mathrm{H}_{2} \mathrm{~S}$ and potential sulfide detoxification mechanisms in nereid polychaetes. $\mathrm{H}_{2} \mathrm{~S}$ is produced when bacteria reduce sulfates and putrefy proteins. Total sulfides in interstitial water of marine sediments commonly range from 1 to $300 \mathrm{mg} / \mathrm{L}$ [40,47-50]. In contrast, interstitial $\mathrm{H}_{2} \mathrm{~S}$ concentrations are one to several orders of magnitude lower: 1 to $30 \mu \mathrm{g} / \mathrm{L}$ in bioturbated sediments and up to $100 \mu \mathrm{g} / \mathrm{L}$ is undisturbed anoxic sediments $[45,48,49,51,52]$. Low interstitial concentrations of $\mathrm{H}_{2} \mathrm{~S}$ are due to its removal as insoluble sulfides, primarily as FeS $[39,46]$. In addition, some infaunal invertebrates have evolved strategies for excluding or detoxifying $\mathrm{H}_{2} \mathrm{~S}$ [53-55]. Vismann [56] recently demonstrated that the blood, intestinal wall, and intestinal fluid of two nereid polychaetes (Nereis (Hediste) diversicolor and Nereis (Neanthes) virens) are capable of detoxifying $\mathrm{H}_{2} \mathrm{~S}$ via sulfide oxidation. It is likely that their congener, $N$. arenaceodentata, has similar capabilities. $\mathrm{H}_{2} \mathrm{~S}$ does not appear to be a serious nontreatment factor in chronic sediment bioassays with $N$. arenaceodentata, based on (a) the parts-per-billion in situ interstitial water concentrations of $\mathrm{H}_{2} \mathrm{~S}$, (b) the high survival of $N$. arenaceodentata to partsper-million-level $\mathrm{H}_{2} \mathrm{~S}$ exposures, and (c) the sulfide-detoxifying capabilities in nereid polychaetes.

\section{Future research}

The development of a chronic sublethal sediment bioassay with $N$. arenaceodentata still requires considerable research and development in a number of areas. These may be grouped into three general categories: methods development, interpretive guidance, and sensitivity analysis. An important and complex methodological issue to be resolved is the influence of food ration on bioassay test results. The presence or absence of food may increase or decrease sediment toxicity in a complex and unpredictable manner. For example, if adequate nutritious food is furnished during sediment exposures, juvenile worms may feed on this ration preferentially and not ingest the contaminated sediment. If inadequate or no food is provided, sediment ingestion, and thus contaminant exposure, will likely increase. Tests conducted on the same sediment using these different feeding scenarios would likely yield disparate results. Differences in nutritional quality among test sediments may also significantly affect results. For example, worms exposed to nutritionally rich sediment (i.e., high organic content) may grow larger than worms exposed to an organically poor sediment. Although this does not seem to be problematic, the paradox is that nutritionally rich fine-grain sediments also tend to have high contaminant loadings. Clearly, additional research on the influence of food is required.

Another potentially important and often overlooked methodological question is the effect of photoperiod. Constant illumination is used in some sediment bioassays to encourage test species to remain within the sediments (most infauna are photonegative). This action presumably maximizes contaminant exposure and test sensitivity. Constant illumination, however, is unnatural and may represent a significant stressor to the organism. Photoperiod is known to affect feeding, growth, and general activity in a variety of polychaete species $[36,57,58]$. Our own laboratory observations indicate that $N$. arenaceodentata is rarely found on the sediment surface during the day, but nocturnal epibenthic excursions are common. Future research should address the potential influence of photoperiod on chronic sublethal sediment bioassays.

To have regulatory utility, any chronic sublethal sediment bioassay must be accompanied by technically sound interpretive guidance. For the growth assays with $N$. arenaceodentata, this guidance must be able to answer the following question, "What diminution in growth is biologically important?" For example, if a $15 \%$ decrease in growth is statistically significant, is that difference biologically important? What is the minimum level of growth (milligrams dry weight or milligrams dry weight per day) for $N$. arenaceodentata? To provide answers 
to these questions, one must evaluate the quantitative relationship between growth and reproductive success. Moreover, the technical basis for this guidance must have predictive value. Experiments to examine the relationship between growth and reproduction in $N$. arenaceodentata are currently being conducted.

The sensitivity of this or any other sediment bioassay is a function of three elements: (a) test conditions, (b) in situ contaminant exposure, and (c) species sensitivity. Important test conditions that can affect bioassay results were discussed above. In situ contaminant exposure will vary with the species and the test conditions. Exposures are affected by the organism's behavior, source of ingested sediment (suspended, surficial, subsurface), and respiratory water (interstitial, overlying) $[3,59]$. Tube habitation may also increase or decrease contaminant exposure, depending on redox-mediated contaminant migration and the overlying water quality [60]. Finally, species sensitivity can affect test sensitivity. Comprehensive reviews have concluded that there is no single species, family, or class of animal that is most sensitive to environmental pollutants [61-63]. Identifying the most sensitive species exposed to a complex mixture of chemicals embedded in a mineralogical matrix is, therefore, highly problematic. The most appropriate approach is to evaluate test sensitivity via side-by-side comparisons with other bioassays using the same sediment at the same time. To our knowledge, this has been done only once when growth in $N$. arenaceodentata was involved [64]. In that study, the sensitivity of $N$. arenaceodentata exposed to sediments from three Superfund sites approximated that observed for two amphipod species ( $R$. abronius and Eohaustorius estuarius). Worm survival was significantly reduced in all three sediments, whereas amphipod survival was reduced in two out of the three. When all sediment dilutions were considered, worm growth and amphipod mortality were significantly reduced in five and six instances, respectively. Both worm and amphipod bioassays were considerably less sensitive than two other tests: echinoderm embryo development and Microtox ${ }^{\circledR}$ with organic extract [65]. Similar studies with a greater diversity of fieldcollected sediments are needed to evaluate properly the sensitivity of the $N$. arenaceodentata growth assay. This, however, can be done only after a technically sound consensus protocol has been firmly established.

Acknowledgement - Insightful reviews were provided by Francis J. Reilly, Jr., AScI Corporation, and Charles Lutz of the U.S. Army Engineer (USAE) Waterways Experi- ment Station, as well as two anonymous reviewers. Funding for this work was provided by the USAE District, San Francisco, as well as the U.S. Army Corps of Engineers (USACE) Long-Term Effects of Dredging Operations (LEDO) program, Work Unit 32468. The LEDO program is sponsored by the USACE headquarters. Permission was granted by the Chief of Engineers to publish this information.

\section{REFERENCES}

1. Swartz, R.C. 1987. Toxicological methods for determining the effects of contaminated sediment on marine organisms. In K.L. Dickson, A.W. Maki and W.A. Brungs, eds., Fate and Effects of SedimentBound Chemicals in Aquatic Systems. Pergamon, Elmsford, NY, pp. 183-198.

2. Burton, G.A. 1990. Assessing the toxicity of freshwater sediments. Environ. Toxicol. Chem. 10:15851627.

3. Adams, W.J. 1987. Bioavailability of neutral lipophilic organic chemicals contained on sediments: A review. In K.L. Dickson, A.W. Maki and W.A. Brungs, eds., Fate and Effects of Sediment-Bound Chemicals in Aquatic Systems. Pergamon, Elmsford, NY, pp. 219-244.

4. Knox, G.A. 1977. The role of polychaetes in benthic soft-boltom communities, In D.J. Reish and K. Fauchald, eds., Essays on Polychaetous Annelids. Allan Hancock Foundation, Los Angeles, CA, pp. 547-604.

5. Zajac, R.N. 1985. The effects of sublethal predation on reproduction in the spionid polychaete Polydora ligni Webster. J. Exp. Mar, Biol. Ecol. 88:1-19.

6. Zwarts, L. and P. Esselink. 1989. Versatility of male curlews Numenius arquata preying upon Nereis diversicolor: Deploying contrasting capture modes dependent on prey availability. Mar. Ecol. Prog. Ser. 56:255-269.

7. Iluttel, M. 1990. Influence of the lugworm Arenicola marina on porewater nutrient profiles of sand flat sediments. Mar. Ecol. Prog. Ser. 62:241-248.

8. Aller, R.C. and J.Y. Yingst. 1978. Biogeochemistry of tube-dwellings: A study of the sedentary polychaete Amphitrite ornata (Leidy). J. Mar. Res. 36:201-254.

9. Kristensen, E. and T.H. Blackburn. 1987. The fate of organic carbon and nitrogen in experimental marine sediment systems: Influence of bioturbation and anoxia. J. Mar. Res. 45:231-257.

10. Meadows, P.S., J. Tait and S.A. Hussain. 1990. Effects of estuarine infauna on sediment stability and particle sedimentation. Hydrobiologia 190:263-266.

11. Reish, D.J. 1957. The life history of the polychaetous annelid Neanthes caudata (delle Chiaje), including a summary of development in the family Nereidae. Pac. Sci. 11:216-228.

12. Pettibone, M.H. 1963. Marine polychaete worms of the New England region. 1. Aphroditidae through Trochochaetidae. U.S. National Museum Bulletin 227. Smithsonian Institution, Washington, DC.

13. Day, J. 1973. New Polychaeta from Beaufort with a key to all species recorded from North Carolina. NOAA Technical Report 375. National Oceanic and Atmospheric Administration, Washington, DC.

14. Whitlatch, R.B. 1977. Seasonal changes in the community structure of the macrobenthos inhabiting the 
intertidal sand and mud flats of Barnstable Harbor, Massachusetts. Biol. Bull. 152:275-294.

15. Taylor, J.L. 1984. Family Nereidae Johnston, 1845. In J.M. Uebelacker and P.G. Johnson, eds., Taxonomic Guide to the Polychaetes of the Northern Gulf of Mexico. U.S. Department of the Interior, Metairie, LA, pp. 14-15.

16. Whitlatch, R.B. 1980. Patterns of resource utilization and coexistence in marine intertidal deposit-feeding communities. J. Mar. Res. 38:743-765.

17. U.S. Environmental Protection Agency and U.S. Army Corps of Engineers. 1991. Evaluation of dredged material proposed for ocean disposal (testing manual). Implementation manual for $\$ 103$ of Public Law 92-532. EPA 503/8-91-001. U.S. Army Engineer Waterways Experiment Station, Vicksburg. MS

18. Reish, D.J. 1985. The use of the polychaetous annelid Neanthes arenaceodentata as a laboratory experimental animal. Tethys 11:335-341.

19. Weinberg, J.R., V.R. Starczak, C. Mueller, G.C. Pesch and S.M. Lindsay. 1990. Divergence between populations of a monogamous polychaete with male parental care: Premating isolation and chromosome variation. Mar. Biol. 107:205-213.

20. Pesch, C.E. and G.L. Hoffman. 1983. Interlaboratory comparison of a 28-day toxicity test with the polychaete Neanthes arenaceodentata. In W.E. Bishop, R.D. Cardwell and B.B. Heidolph, eds. Aquatic Toxicology and Hazard Assessment (Sixth Symposium). STP 802. American Society for Testing and Materials, Philadelphia, PA, pp. 482-493.

21. Reish, D.J. 1974. The establishment of laboratory colonies of polychaetous annelids. Thalassia Jugoslavica 10:181-195.

22. Pesch, C.E. and P.S. Schauer. 1988. Flow-through culture techniques for Neanthes arenaceodentata (Annelida: Polychaeta), including influence of diet on growth and survival. Environ. Toxicol. Chem. 7:961-968.

23. Reish, D.J. 1980. Use of polychaetous annelids as test organisms for marine bioassay experiments. In A.L. Buikema, Jr. and J. Cairns, Jr., eds., Aquatic Inver. tebrate Bioassays. STP 715. American Society for Testing and Materials, Philadelphia, PA, pp. 140-154.

24. Pesch, C.E., R.N. Zajac, R.B. Whitlatch and M.A. Balboni. 1987. Effect of intraspecific density on life history traits and population growth rate of Neanthes arenaceodentata (Polychaeta: Nereidae) in the laboratory. Mar. Biol. 96:545-554.

25. Anderson, S.L., F.L. Harrison, G. Chan and D.H. Moore II. 1990. Comparison of cellular and wholeanimal bioassays for estimation of radiation effects in the polychaete worm (Neanthes arenaceodentata). Arch. Environ. Contam. Toxicol. 19:164-174.

26. Patrick, W.H. 1958. Modification of method of particle size analysis. Soil Sci. Soc. Am. Proc. 22:366367.

27. Hampson, B.L. 1977. Relationship between total ammonia and free ammonia in terrestrial and ocean waters. J. Cons. Int. Explor. Mer. 37:117-122.

28. Wilkinson, L. 1988. SYSTAT ${ }^{\oplus}$ : The System for Statistics. SYSTAT, Evanston, IL.

29. Sokal, R.R. and J.F. Rohlf. 1981. Biometry, 2nd ed. W.H. Freeman, New York, NY.
30. Clark, R.B. and U. Scully. 1964. Hormonal control of growth in Nereis diversicolor. Gen. Comp. Endocrinol. 4:82-90.

31. Davis, W.R. and D.J. Reish. 1975. The effect of reduced dissolved oxygen concentration on the growth and production of oocytes in the polychaetous annelid Neanthes arenaceodentata. Rev. Int. Oceanogr. Med. Tomes 37/38:3-16.

32. Eckelbarger, K.J. 1986. Vitellogenic mechanisms and the allocation of energy to offspring in polychaetes. Bull. Mar. Sci. 29:426-443.

33. Clark, R.B. 1965. Endocrinology and the reproductive biology of polychaetes. Oceanogr. Mar. Biol. Ann. Rev. 3:211-255.

34. DeWitt, T.H., G.R. Ditsworth and R.C. Swartz. 1988. Effects of natural sediment features on survival of the phoxocephalid amphipod Rhepoxynius abronius. Mar. Environ. Res, 25:99-124.

35. Kristensen, E. 1988. Factors influencing the distribution of nereid polychaetes in Danish coastal waters. Ophelia 29:127-140.

36. Clark, R.B. 1959. The tubicolous habit and the fighting reactions of the polychaete Nereis pelagica. Anim. Behav. 7:85-90.

37. Starczak, V.R. 1984. Sexual selection and intrasexual aggression in the marine polychaete Nereis (Neanthes) acuminata. Ph.D. thesis. University of Connecticut, Storrs, CT.

38. U.S. Environmental Protection Agency. 1985. Ambient water quality criteria for ammonia - 1984. EPA 440/5-85-001. Office of Water Regulations and Standards, Washington, DC.

39. Santschi, P., P. Hohener, G. Benoit and M.B. Brink. 1990. Chemical processes at the sediment-water interface. Mar. Chem. 30:269-315.

40. Murray, J.W., V. Grundmanis and W.M. Smethic, Jr. 1978. Interstitial water chemistry in the sediments of Saanich Inlet. Geochim. Cosmochim. Acta 42:10111026.

41. Ankley, G.T., A. Katko and J.W. Arthur. 1990. Identification of ammonia as an important sediment-associated toxicant in the lower Fox River and Green Bay, Wisconsin. Environ. Toxicol. Chem. 9:313-322.

42. Jones, R.A. and G.F. Lee. 1988. Toxicity of U.S. waterway sediments with particular reference to the New York Harbor area. In J.J. Lichtenberg, F.A. Winter, C.I. Weber and L. Fradkin, eds., Chemical and Biological Characterization of Sludges, Sediments, Dredged Soils and Drilling Muds. STP 976. American Society for Testing and Materials, Philadelphia, PA. pp. 403-417.

43. Prosser, C.L. 1973. Oxygen: Respiration and metabolism. In C.L. Prosser, ed., Comparative Animal Physiology, 3rd ed. W.B. Saunders, Philadelphia, PA, pp. 165-211.

44. Smith, L., D. Oseid and L. Olson. 1976. Acute and chronic toxicity of hydrogen sulfide to the fathead minnow Pimephales promelas. Environ. Sci. Technol. 10:565-568.

45. Main, M.B. and W.G. Nelson. 1988. Tolerance of the sabellarid polychaete Phragmatopoma lapidosa Kinberg to burial, turbidity, and hydrogen sulfide. Mar. Environ. Res. 26:9-55.

16. Ponnamperuma, F.N. 1972. The chemistry of submerged soils. Adv. Agron. 24:29-88. 
47. Berner, R. 1963. Electrode studies of hydrogen sulfide in marine sediments. Geochim. Cosmochim. Acta 27:563-575.

48. U.S. Army Corps of Engineers. 1975. Dredge disposal study, San Francisco Bay and Estuary, Appendix Fcrystalline matrix study: U.S. Army Engineer District, San Francisco, CA.

49. King, G.M., M.J. Klug, R.G. Weigert and A.G. Chalmers. 1982. Relation of soil water movement and sulfide concentration to Spartina alterniflora production in a Georgia salt marsh. Science 218:61-63.

50. Howarth, R.W., A. Giblin, J. Gale, B.J. Peterson and G.W. Luther III. 1983. Reduced sulfur compounds in the pore waters of a New England salt marsh. Ecol. Bull. 35:135-152.

51. McLachlan, A. 1978. A quantitative analysis of the meiofauna and the chemistry of the redox potential discontinuity zone in a sheltered sandy beach. Estuarine Coastal Mar. Sci. 7:275-290.

52. Emerson, S., R. Jahnke and D. Heggie. 1984. Sediment-water exchange in shallow water estuarine sediments. J. Mar. Res. 42:709-730.

53. Powell, E.N., M.A. Crenshaw and R.M. Rieger. 1979. Adaptations to sulfide in the meiofauna of the sulfide system. I. ${ }^{35} \mathrm{~S}$-sulfide accumulation and the presence of a sulfide detoxification system. J. Exp. Mar. Biol. Ecol. 37:57-76.

54. Arp, A.J. and Childress, J.J. 1983. Sulfide binding by the blood of the hydrothermal vent tube worm Riftia pachyptila. Science 219:295-297.

55. Powell, M.A. and G.N. Somero. 1983. Blood components prevent sulfide poisoning of respiration of the hydrothermal vent tube worm Riftia pachyptila. Science 219:297-299.

56. Vismann, B. 1990 . Sulfide detoxification and tolerance in Nereis (Hediste) diversicolor and Nereis (Neanthes) virens (Annelida: Polychaeta). Mar. Ecol. Prog. Ser. 59:229-238.
57. Gremare, A. 1988. Feeding, tube-building and particle-size selection in the terebellid polychaete $E u$ polymnia nebulosa. Mar. Biol. 97:243-252.

58. Chu, J.-W. and L.A. Levin. 1989. Photoperiod and temperature regulation of growth and reproduction in Streblospio benedicti (Polychaeta: Spionidae). Invert. Rep. Dev. 15:131-142.

59. Landrum, P.F. and J.A. Robbins. 1990 . Bioavailability of sediment-associated contaminants to benthic invertebrates. In R. Baudo, J.P. Giesy and H. Muntau, eds., Sediments: Chemistry and Toxicity of In-Place Pollutants. Lewis, Chelsea, MI, pp. 237-263.

60. Aller, R.C. 1982. The effects of macrobenthos on chemical properties of marine sediment and overlying water. In P.L. McCall and M.J.S. Tevesz, eds., Animal-Sediment Relations. The Biogenic Alteration of Sediments. Plenum, New York, NY, pp. 53-102.

61. Kenega, E.E. 1978. Test organisms and methods useful for early assessment of acute toxicity of chemicals. Environ. Sci. Technol. 12:1322-1329.

62. Mount, D. 1982. Aquatic surrogates. Surrogate Species Workshop Report. TR-507-36B. U.S. Environmental Protection Agency, Washington, DC, pp. A6-2 to A6-4.

63. Mayer, F.L. and M.R. Ellersieck. 1986. Manual of acute toxicity: Interpretation and data base for $\mathbf{4 1 0}$ chemicals and 66 species of freshwater animals. U.S. Fish Wildl. Serv. Resour. Publ. 160.

64. Pastorok, R.A. and D.S. Becker. 1990. Comparative sensitivity of sediment toxicity bioassays at three $\mathrm{Su}$ perfund sites in Puget Sound. In W.G. Landis and W.H. van der Schalie, eds., Aquatic Toxicology and Hazard Assessment. STP 1096. American Society for Testing and Materials, Philadelphia, PA. pp. 123-139.

65. Schiewe, M.H., E.G. Hawke, D.I. Actor and M.M. Krakn. 1985. Use of a bacterial bioluminescence assay to assess toxicity of contaminated marine sediments. Can. J. Fish Aquat. Sci. 42:1244-1248. 


\section{Conclusions}

Initial development of a chronic sublethal sediment bioassay for the evaluation of dredged material is described. The test is initiated with 2- to 3-week-old juvenile polychaete worms, Nereis (Neanthes) arenaceodentata, and terminated after 28 days. The sublethal test end point is estimated individual somatic growth rate (milligrams dry weight/day). The potential influence of selected nontreatment factors on bioassay results was evaluated. Grain size (5 to 100 percent sand) had no effect, while the number of worms added to each exposure vessel was critical. Seawater salinities of 20 to $30 \%$ had no effect on either survival or growth, while salinities $\leq 15 \%$ had highly significant adverse effects. Both survival and growth of juvenile worms may be adversely affected if test conditions involve exposures to $\geq 20 \mathrm{mg} / \mathrm{L}$ total ammonia ( $0.68 \mathrm{mg} / \mathrm{L}$ un-ionized ammonia) or $\geq 5.5 \mathrm{mg} / \mathrm{L}$ hydrogen sulfide.

Survival of juvenile worms to the reference toxicant, cadmium chloride, was used as a quality control measure. Results are expressed in control chart format analogous to methods used by analytical chemists. 


\section{Recommendations}

- Early development of a chronic sublethal sediment bioassay with the polychaete worm Nereis (Neanthes) arenaceodentata appears promising and should be continued.

- The bioassay may be initiated with worms no older than 2 to 3 weeks and continued for 28 days. At test termination, worms must not be older than 6 to 7 weeks.

- The bioassay can be conducted with dredged material of any grain size.

- The bioassay should not involve acute transfers to salinities $\leq 15 \%$.

- Total ammonia and hydrogen sulfide concentrations should be no greater than 20 and $5.5 \mathrm{mg} / \mathrm{L}$, respectively.

- A standard reference toxicant test should be conducted with every sediment bioassay, and results expressed in control chart format.

- Future research should focus on developing technically sound interpretive guidance for the growth end point, and initial testing with a wide range of dredged material. 


\section{REPORT DOCUMENTATION PAGE}

Public reporting burden for this collection of information is estimated to average 1 hour per response, including the time for reviewing instructions, searching existing data sources, gathering and maintaining the data needed, and completing and reviewing the collection of information. Send comments regarding this burden estimate or any other aspect of this Davis Highway, Suite 1204, Arlington, VA 22202-4302, and to the Office of Management and Budget, Paperwork Reduction Project (0704-0 188), Washington, DC 20503.

\begin{tabular}{|l|l|l} 
1. AGENCY USE ONLY (Leave blank) & $\begin{array}{c}\text { 2. REPORT DATE } \\
\text { August } 1994\end{array}$ & $\begin{array}{c}\text { 3. REPORT TYPE AND DATES COVERED } \\
\text { Final report }\end{array}$
\end{tabular}

4. TITLE AND SUBTITLE

Development of a Chronic Sublethal Bioassay for Evaluating Contaminated Sediment with the Marine Polychaete Worm Nereis (Neanthes) arenaceodentata

\section{AUTHOR(S)}

Tom M. Dillon, David W. Moore, Alfreda B. Gibson

7. PERFORMING ORGANIZATION NAME(S) AND ADDRESS(ES)

8. PERFORMING ORGANIZATION REPORT NUMBER

U.S. Army Engineer Waterways Experiment Station Environmental Laboratory, 3909 Halls Ferry Road, Vicksburg, MS 39180-6199

Miscellaneous Paper

D-94-5

10. SPONSORING/MONITORING AGENCY REPORT NUMBER

U.S. Army Corps of Engineers, Washington, DC 20314-1000

11. SUPPLEMENTARY NOTES

Available from National Technical Information Service, 5285 Port Royal Road, Springfield, VA 22161.

12a. DISTRIBUTION / AVAILABILITY STATEMENT

12b. DISTRIBUTION CODE

Approved for public release; distribution is unlimited.

13. ABSTRACT (Maximum 200 words)

Development of a chronic sublethal sediment bioassay with the polychaete Nereis (Neathes) arenaceodentata is described. The sublethal test end point was estimated individual somatic growth rate (milligrams dry weight per day). The test was initiated with 2- to 3-week-old postemergent juvenile worms and continued for 28 days. The potential bias due to selected nontreatment factors on polychaete survival and growth was evaluated. For example, grain size had no significant effect, whereas the number of worms placed in each exposure vessel was critical. Direct transfer from $30 \mathrm{ppt}$ seawater to salinities $\leq 15 \mathrm{ppt}$ had a highly significant and adverse effect on survival and growth. Both survival and growth of juvenile worms may be adversely affected if test conditions involve exposures to $\geq 0.7 \mathrm{mg} / \mathrm{L}$ un-ionized ammonia or $\geq 5 \mathrm{mg} / \mathrm{L}$ hydrogen sulfide. Survival of juvenile worms to concentrations of the reference toxicant, cadmium chloride, approximating the $96-\mathrm{hr} \mathrm{LC}_{50}(5 \mathrm{mg} / \mathrm{L})$ was used as a quality control measure. Results are expressed in control chart format analogous to methods used in analytical chemistry.

\begin{tabular}{|c|c|c|c|}
\hline \multirow{2}{*}{$\begin{array}{ll}\text { 14. SUBJECT TERMS } & \\
\text { Chronic } & \text { Neanthes } \\
\text { Growth } & \text { Sediment }\end{array}$} & \multirow{2}{*}{\multicolumn{2}{|c|}{ Sublethal }} & $\begin{array}{l}\text { 15. NUMBER OF PAGES } \\
26\end{array}$ \\
\hline & & & 16. PRICE CODE \\
\hline $\begin{array}{l}\text { 17. SECURITY CLASSIFICATION } \\
\text { OF REPORT } \\
\text { Unclassified }\end{array}$ & $\begin{array}{l}\text { 18. SECURITY CLASSIFICATION } \\
\text { OF THIS PAGE } \\
\text { Unclassified }\end{array}$ & $\begin{array}{l}\text { 19. SECURITY CLASSIFICATION } \\
\text { OF ABSTRACT }\end{array}$ & 20. LIMITATION OF ABSTRACT \\
\hline \multicolumn{3}{|l|}{ NSN $7540-01-280-5500$} & $\begin{array}{l}\text { indard Form } 298 \text { (Rev. 2-89) } \\
\text { scribed by ANSI std. } 239-18 \\
102\end{array}$ \\
\hline
\end{tabular}

